\title{
HCMV gB GENOTYPES IN CERVICAL SECRETION AND PLACENTA TISSUES IN THE STATE OF ESPÍRITO SANTO, SOUTHEASTEARN BRAZIL
}

\section{Liliana Cruz Spano $^{1 *}$; Mônica Simões Rocha Ferreira ${ }^{2}$; Marilda Santos Almeida² ${ }^{2}$ Jussara Pereira do Nascimento $^{3}$; José Paulo Gagliardi Leite ${ }^{2}$}

'Departamento de Patologia e Núcleo de Doenças Infecciosas, Centro de Ciências da Saúde, Universidade Federal do Espírito Santo, Vitória, ES, Brasil; ${ }^{2}$ Laboratório de Virologia Comparada, Instituto Oswaldo Cruz, Fundação Instituto Oswaldo Cruz, Rio de Janeiro, RJ, Brasil; ${ }^{3}$ Departamento de Microbiologia e Parasitologia, Centro Biomédico, Universidade Federal Fluminense,

Niterói, RJ, Brasil.

Submitted: September 21, 2006; Returned to authors for corrections: March 12, 2007; Approved: June 21, 2007.

\begin{abstract}
Human cytomegalovirus (HCMV) displays genetic variability in several regions, supposed to be related with strain-specific tissue tropism and immunopathogenesis. Based on sequence variation in the UL55 gene that encodes gB glycoprotein, HCMV strains can be assigned to one of four genotypes. Previous studies have addressed $\mathrm{gB}$ genotyping mostly by investigating strains derived from immunosuppressed patients, sometimes without previous knowledge about genotype distribution in a geographic area. The present study verified the distribution of HCMV gB genotypes of strains obtained from immunocompetent women at Vitória City, Espírito Santo State, Southeastern, Brazil. The HCMV genome was extracted from their cervical secretion, fetal and maternal placenta tissues (chorionic villous and decidua) from abortion cases and from white blood cells (WBCs). HCMV genotyping was performed by restriction fragment length polymorphism analyses of amplified product from the high variability site of the UL55 gene. All four genotypes were observed in both cervical secretion and placenta, whereas in WBCs a single gB1 genotype was detected. HCMV gB1 and gB2 genotypes were detected, respectively, in nine and in six of the 23 studied samples, while gB3 and gB4 were each found in four separate samples of the total. The differences in genotype frequency were not considered statistically significant. No mixed genotype infection was observed. The results indicated that the four $\mathrm{gB}$ HCMV genotypes had no particular tropism for placenta tissues and that all genotypes circulated within immunocompetent women at the time and in the region of study.
\end{abstract}

Key words: cytomegalovirus; RFLP; gB genotypes; cervical secretion; placenta tissues

\section{INTRODUCTION}

Human cytomegalovirus (HCMV), a widely distributed $\beta$ herpesvirus, is the leading agent of congenital infection $(2,38)$, causes significant morbidity and mortality among immunocompromised patients $(16,23)$ but is seldom responsible for symptomatic infections in immunocompetent patients (19). HCMV establishes latent infection associated with reactivation episodes during which it may be excreted from saliva, urine, cervical secretion, sperm and breast milk $(12,28,37)$.

HCMV strains display nucleotide polymorphism in several functionally important genes that encode $\mathrm{gB}$ (UL55), gH (UL75), gN (UL73) glycoproteins or UL144 region, supposed to be involved in viral virulence and explored as genotype systems. HCMV gB glycoprotein, the major antigen involved in induction of neutralizing antibodies (11), is associated with adsorption, penetration of the host cell, and cellular fusion

*Corresponding Author. Mailing address: UFES - Núcleo de Doenças Infecciosas - Centro de Ciências da Saúde - Av. Marechal Campos, 1468 - Maruípe

- 29043-900. Vitória, ES - Brasil. Tel.: (27) 3335-7210 ou (27) 3335-7206. E-mail: 1spano@ndi.ufes.br 
$(24,25,41)$; gH glycoprotein is related with cellular fusion (18); $\mathrm{gN}$, with adsorption and cell to cell dissemination (31) and UL144 encodes for a putative member of the tumor necrosis factor- $\alpha$-like receptor superfamily with unknown function $(21,30)$.

Based on the restriction fragment length polymorphism (RFLP) of amplification products of HCMV gB (bases 13191604), four patterns (gB1-gB4) have been observed $(9,10)$. According to these profiles, a genotyping system was then proposed and conventionally accepted as a putative marker of development of HCMV-associated disease.

In this direction, several studies have been carried out that have attempted to verify an association between the gB HCMV genotype and disease manifestations. Some have supported a possible association between viral tropism/pathogenicity and the $\mathrm{gB}$ gene $(15,22)$ whereas others have found no evidence whatsoever of a gB-virulence association $(17,33,42)$. But, to date, little attention has been given to HCMV strains in immunocompetent individuals $(4,27)$ and by this time, concern has begun on those strains involved in congenital infection (4$6,20,29,39)$.

Studies of HCMV gB genotypes have been done directly from clinical specimens: blood, urine, semen and/or saliva $(3,9,13,22,33,44)$, or after viral isolation in cell culture $(4,5,27,39,42)$. At the present time, studies on HCMV gB genotypes employing such clinical specimens as cervical secretion and placenta tissues (chorionic villous or decidua) are absent or with rare description (40). Therefore, the aim of this study was to describe the frequency of HCMV $\mathrm{gB}$ genotypes from strains detected in cervical secretion from healthy women, and those that could infect placenta. HCMV strains were directly genotyped from clinical samples, with the advantage of avoiding mutation during viral in vitro replication while favoring the selection of strains affording greater opportunity for cellular replication (8). The revealed genotypes would permit future support on congenital infection and fetal or newborn tropism and consequences beyond the relevance on epidemiological knowledge.

\section{MATERIALAND METHODS}

\section{Specimens}

Twenty three HCMV strains were derived from the following positive specimens: i) 12 cervical secretions obtained from 102 immunocompetent pregnant and non-pregnant women (mean age 26 years), ii) eight placenta tissues (deciduas or chorionic villi) obtained from 88 abortion cases, and iii) three obtained from white blood cells (WBCs) - two from 100 pregnant and non-pregnant women and one from 95 women undergoing an abortion $(35,36)$. Each strain was recovered from a different woman. Sample handling, storage and DNA extractions have been previously reported $(35,36)$.

\section{PCR and nested PCR for gB gene}

Extraction products were subjected to gB gene HCMV amplification corresponding to high variability in the $\mathrm{gB}$ gene sequence. The outer and inner gB primers (gB1868N, gB829N and $\mathrm{gB} 1319 \mathrm{~N}, \mathrm{gB} 1604$, respectively) were used in accordance with the criteria previously described (33). The amplification protocol used was established in the present paper. PCR and nested-PCR mix solutions contained in a total volume of $50 \mu \mathrm{L}$ : $1.5 \mathrm{mM} \mathrm{MgCl} 2$, PCR buffer (20 mM tris- $\mathrm{HCl} \mathrm{pH} 8.4,50 \mathrm{mM} \mathrm{KCl}$ ), $200 \mu \mathrm{M}$ each of the four dNTPs, 1.5 units of Taq DNA polymerase (Life Technologies ${ }^{\mathrm{TM}}$, Inc., MD, USA) and 20 pmol of each outer or inner primers. For PCR reaction, $15 \mu \mathrm{L}$ of extracted DNA was added to $35 \mu \mathrm{L}$ of mix solution. The first round of amplification was undertaken with one denaturation cycle at $95^{\circ} \mathrm{C}$ for $5 \mathrm{~min}$ and thirty-five amplification cycles consisting of $60 \mathrm{sec}$ each at $94^{\circ} \mathrm{C}$ and $90 \mathrm{sec}$ for annealing and primer extension at $72^{\circ} \mathrm{C}$, followed by a $72^{\circ} \mathrm{C}$ final extension for $5 \mathrm{~min}$. The PCR products were used as a template in a nestedPCR assay. The second round amplification was undertaken with initial denaturation at $94^{\circ} \mathrm{C}$ for $2 \mathrm{~min}$, followed by thirtyfive cycles consisting of $30 \mathrm{sec}$ each at $94^{\circ} \mathrm{C}$ and $30 \mathrm{sec}$ at $72^{\circ} \mathrm{C}$ and then by a $72^{\circ} \mathrm{C}$ final extension for $5 \mathrm{~min}$. All precautions to avoid cross-contamination and amplification inhibition were observed by using water and $\beta$-globin gene amplification as negative and positive controls, respectively, during all procedures $(35,36)$. PCR and nested-PCR resulted in DNA fragments of approximately $1036 \mathrm{bp}$ and $305 \mathrm{bp}$, respectively, which were resolved on a $1.5 \%$ agarose gel (Invitrogen ${ }^{\mathrm{TM}}$, Carlsbad, CA, USA) and stained with $0.5 \mu \mathrm{g} / \mathrm{mL}$ ethidium bromide (Sigma, St Louis, MO, USA).

\section{Restriction Fragment Length Polymorphism Analysis}

To identify the HCMV genotype, nested-PCR products were separately digested with 10 units of restriction endonucleases $R s a \mathrm{I}$ and HinfI (Invitrogen ${ }^{\mathrm{TM}}$, Inc., MD, USA), after incubation in the appropriate buffer at $37^{\circ} \mathrm{C}$ overnight. The digestion products were resolved on $4.0 \%$ MetaPhor agarose gels (FMC BioProducts, Rockland, Maine, USA) and stained with ethidium bromide (Sigma).

\section{RESULTS}

The $\mathrm{gB}$ digestion products were adequately assigned to one of the gB1-gB4 genotypes (Fig. 1) according to the restriction fragments (estimated to be from 36 to $240 \mathrm{bp}$ ) as previously proposed (9). All four HCMV gB genotypes were found in the 12 vaginal secretions collected from both immunocompetent pregnant and non-pregnant women as well as from the eight abortion tissues (Table 1). No particular genotype was found to predominate in either of these two groups and no mixed infection was observed. The HCMV gB1 genotype was the only one recovered in the three WBCs 

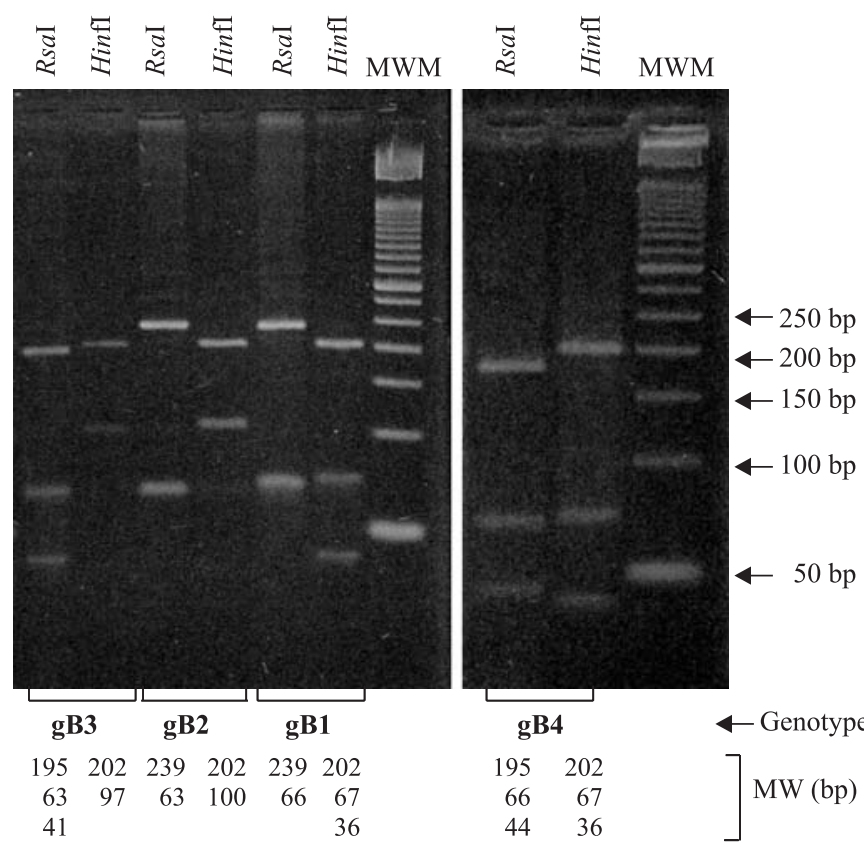

Figure 1. Ethidium-bromide-stained $4 \%$ MetaPhor agarose gel, showing patterns of amplified $g B$ gene (1319-1604 bases) fragments following restriction digestion. RsaI and HinfI enzymes yielded distinguishable digest profiles for groups 1-4 as defined in the figure. $\mathrm{gB}$ genotypes and estimated weights of digestion fragments [9] are below each lane. MWM: $50 \mathrm{bp}$ molecular weight marker. MW: estimated molecular weights.

Table 1. HCMV gB genotype distribution among clinical specimens obtained from immunocompetent women.

\begin{tabular}{ccccc}
\hline \multirow{2}{*}{$\begin{array}{c}\text { HCMV gB } \\
\text { Genotype }\end{array}$} & \multicolumn{4}{c}{ Clinical Specimens } \\
\cline { 2 - 5 } & Secretion $^{\mathrm{a}}$ & Tissue $^{\mathrm{b}}$ & WBCs $^{\mathrm{c}}$ & Total $^{\mathrm{d}}$ \\
\hline gB1 & 4 & 2 & 3 & $9(39.1 \%)$ \\
gB2 & 3 & 3 & 0 & $6(26.1 \%)$ \\
gB3 & 2 & 2 & 0 & $4(17.4 \%)$ \\
gB4 & 3 & 1 & 0 & $4(17.4 \%)$ \\
\hline Total & 12 & 8 & 3 & 23 \\
\hline
\end{tabular}

${ }^{\mathrm{a} C o l l e c t e d ~ f r o m ~ p r e g n a n t ~ a n d ~ n o n-p r e g n a n t ~ w o m e n ; ~}$

${ }^{\mathrm{b}}$ Collected from abortion cases;

${ }^{\mathrm{c}} \mathrm{WBCs}=$ white blood cells, collected from pregnant (1), non-pregnant (1) and abortion cases (1);

${ }^{\mathrm{d}}$ Statistical analysis was performed using the $\chi^{2}$ test $\left(\chi^{2}=2.91 ; P=0.40\right)$.

specimens. gB1 genotype seemed to predominate in all the investigated samples ( 9 out of 23), followed by gB2 ( 6 out of 23 ) and by gB3 (4 out of 23) and gB4 (also 4 out of 23 ).
Although, percentage-wise, differences were observed, they were not found to be statistically significant $(P=0.40)$, as analyzed by EPI-Info version $6.04 \mathrm{~b}$ using chi-square test.

\section{DISCUSSION}

Genotype characterization of HCMV strains that circulate in a population in a certain geographic area is of upmost importance to elucidate studies on viral tropism and virulence markers. In this study we identified the four $\mathrm{gB}$ genotypes, previously described $(9,10)$, from immunocompetent women, in both cervical secretion and placenta.

It is noteworthy that, although limited by the small number of HCMV strains from tissues obtained from the 88 abortions cases, gB1-gB4 genotypes could be observed on chorionic villi and/or deciduas. HCMV found in placenta tissues from abortion cases can represent latent and/or active viral infection. The virus could conceivably reach the placenta tissue by hematogenic dissemination or contiguous endometrial cell infection $(14,34)$. Therefore, taking into account that the four HCMV gB genotypes were also detected in vaginal secretion, it would be reasonable to expect that abortion tissues could be infected with any one of these strains. The fact that the four HCMV gB types were also found in placenta tissues suggests that there is no specific genotype tropism for placenta tissue infection. However, whether the strains recovered on placenta tissue would reflect the strains in congenital infection remains to be determinated.

As recently reported, all four $\mathrm{gB}$ genotypes were capable of causing congenital infection in North American, Italian and French babies $(4-6,29)$ and in Chinese infants, except by gB4 genotype (43). Similar findings were observed when gN or UL144 were used as virulence markers $(29,32)$. Any link between the genotypes and the severity of congenital diseases were associated with specific genotypes in the previous mentioned studies, although Arista et al. (4) suggested that gB1 could have a peculiar tropism for placental tissues. In contrast with these above citations, Lukácsi et al. (20), in Southern Hungary, found only the gB1 genotype in congenital infection, but the genotypic distribution remained to be elucidated in that population. This fact highlights the importance of our study on establishment of genotypes distribution in specimens more probable to be responsible for congenital infection. Interesting report on $\mathrm{gB}$ distribution in Australian subjects was that certain $\mathrm{gB}$ genotypes were associated more commonly with childhood infections and that these differed from strains associated with invasive disease in HIV adult patients (39).

Distinct HCMV strains had infected the mother after her first pregnancy undergoing a second gestation whose newborns had symptomatic HCMV congenital infection (7). Actually, HCMV remains a problem, calling for immediate additional research in order to elucidate the real potential risks for a 
newborn in regions with high HCMV seroprevalence rates like Brazil, where multiple genotypes circulate, as demonstrated in the present study. Despite the disappointing reports on $\mathrm{gB}$ or UL144 genotypes as a prognostic value in HCMV congenital infection $(4-6,29,30)$, prospective studies indicate that $\mathrm{gB}$ genotypes could serve as a marker of HCMV maternal reinfection by a distinct strain leading to placental and fetal infection.

It is worth pointing out that HCMV seroprevalence in Brazil is around $45 \%$ in children from four-to-nine months of age and as high as $98 \%$ among adults $(26,36)$. The sexual transmission of HCMV has been well established (12), which expose to the continuous viral reinfection and to the occurrence of distinct strains coinfecting the same individual. Nevertheless, in the present study, no mixed HCMV gB genotype infection could be found, which in no way means that the women under study were infected with only one strain. It could reflect that, among immunocompetent women, only one particular strain at a time is reactivated or even that one particular strain may have been detected in a latent state to the detriment of another. Interestingly, the results of this study are in juxtaposition to those of Aquino and Figueiredo (3), who reported a high percentage of HCMV coinfection simultaneously detected in the same or distinct clinical specimens, or in sequential samples, obtained from bone marrow transplant recipients in Ribeirão Preto, São Paulo, in Southeastern Brazil. The population samples of the two studies are quite distinct so that immunosuppression could have favored the viral reactivation of more than one HCMV $\mathrm{gB}$ genotype either at the same or within a very short period of time. Therefore, to better evaluate the possibility of coinfection occurring among immunocompetent women, it would be interesting to follow the course of viral excretion over a prolonged length of time.

While all four above-cited HCMV genotypes were observed in both vaginal secretion and abortion tissue samples, only genotype $\mathrm{gB} 1$ was detected in their three WBCs samples. Arista et al. (4) found a predominant circulation of $\mathrm{gB} 3$ and $\mathrm{gB} 4$ in immunocompetent Italian subjects while Ahumada-Ruiz et al. (1) related gB1 and gB2 in pregnant women and gB2 in blood donors from Costa Rica. Therefore, a different geographic distribution of HCMV gB genotypes is evident from these studies. To determine which genotype is more closely associated to hematogenic dissemination in an immunocompetent population, it would be necessary to study a much larger number of WBC samples and then attempt to correlate the various HCMV types, such as the ones found in others clinical samples as leukocytes, saliva, urine as well as semen.

The results of this study might be of interest to determine the predominance of a particular HCMV gB genotype in congenital infection, regardless the stage in the process. The answer to that question would probably provide some valuable additional information on the possibility of an association between the gB genotype and virulence.
Up to now, a number of reports have indicated that the restriction analyses of $\mathrm{gB}$ gene products remain uncertain as a reliable virulence marker, at least as a single marker. However, they are important in epidemiological studies and should be compared to available data on other putative genetic markers of virulence. Furthermore, as the target of neutralizing antibodies, it would also be interesting to investigate whether $\mathrm{gB}$ might be a marker of coinfection frequency.

Finally, even though a rather limited number of clinical specimens were studied, this report clearly demonstrated that the four different HCMV gB genotypes described herein circulated widely in Southeastern Brazil. However, the genotype distribution amongst other different clinical specimens, as saliva or semen, has yet to be determined. Furthermore, an evaluation of the geographic and demographic differences in the frequency of $\mathrm{gB}$ genotypes would be useful to determine the role of $\mathrm{gB}$ genotypes in virulence.

\section{AKNOWLEDGEMENTS}

This study was partially supported by grants from the Coordenação de Pessoal de Nível Superior (CAPES), Conselho Nacional de Desenvolvimento Científico e Tecnológico (CNPq), Fundação de Amparo à Pesquisa do Estado do Rio de Janeiro (FAPERJ), Instituto Oswaldo Cruz-FIOCRUZ and Universidade Federal do Espírito Santo (UFES), Brazil. Judy Grevan was responsible for editing the English version of the text.

\section{RESUMO}

\section{Genótipos gB de citomegalovírus humano em secreção cervical e placenta no Espírito Santo, Sudeste do Brasil}

O citomegalovírus humano (HCMV) apresenta variabilidade em diversas regiões do genoma, supostamente relacionada ao tropismo tecidual e imunopatogênese viral. Baseando-se na variação de sequiência do gene UL55 que codifica a glicoproteína gB, o HCMV pode ser classificado em um dos quatro genótipos. Estudos prévios têm investigado a associação destes genótipos a partir de cepas obtidas de pacientes imunossuprimidos. O presente estudo determinou os genótipos $\mathrm{gB}$ de cepas de HCMV obtidas de mulheres imunocompetentes em Vitória, Espírito Santo, Sudeste do Brasil. O genoma do HCMV foi extraído de secreção cervical, tecidos placentários fetais e maternos (vilosidade coriônica e decídua) obtidos de casos de aborto e de leucócitos do sangue periférico. A genotipagem foi realizada através da análise de polimorfismo de fragmentos de restrição do produto amplificado da região de alta variabilidade do gene UL55. Todos os quatro genótipos foram detectados na secreção cervical e na placenta, enquanto que somente o genótipo gB1 foi detectado em leucócitos. Genótipos gB1 e 
gB2 foram detectados em nove e seis das 23 cepas estudadas, respectivamente, enquanto $\mathrm{gB} 3 \mathrm{e} \mathrm{gB} 4$ foram encontrados cada um em quatro casos. A diferença na freqüência de genótipos não foi estatisticamente significante. Infecção mista não foi detectada. Estes resultados indicam que os quarto genótipos de HCMV apresentam tropismo para os tecidos placentários e que todos eles circularam nas mulheres imunocompetentes no período e região geográfica do estudo.

Palavras-chave: citomegalovírus; RFLP; genótipo gB, secreção cervical, placenta

\section{REFERENCES}

1. Ahumada-Ruiz, S.; Taylor-Castillo, L.; Visoná, K.; Luftig, R.B.; Herrero-Uribe, L. (2004). Determination of human cytomegalovirus genetic diversity in different patient populations in Costa Rica. Rev. Inst. Med. Trop. São Paulo, 46(2), 87-92.

2. Alford, C.A.; Stagno, S.; Pass, R.F.; Britt, W.J. (1990). Congenital and perinatal cytomegalovirus infection. Rev. Infect. Dis., 12(Suppl 7), 745-753.

3. Aquino, V.H.; Figueiredo, L.T.M. (2000). High prevalence of renal transplant recipients infected with more than one cytomegalovirus glycoprotein B genotype. J. Med. Virol., 61(1), 138-142.

4. Arista, S.; De Grazia, S.; Giammanco, G.M.; Di Carlo, P.; Iannitto, E. (2003). Human cytomegalovirus glycoprotein B genotypes in immunocompetent, immunocompromised, and congenitally infected Italian populations. Arch. Virol., 148(3), 547-554.

5. Bale, J.F.Jr.; Murph, J.R.; Demmler, G.J.; Dawson, J.; Miller, J.E.; Petheram, S.J. (2000). Intrauterine cytomegalovirus infection and glycoprotein B genotypes. J. Infect. Dis., 182(3), 933-936.

6. Barbi, M.; Binda, S.; Caroppo, S.; Primache, V.; Dido, P.; Guidotti, P.; Corbetta, C.; Melotti, D. (2001). CMV gB genotypes and outcome of vertical transmission: study on dried blood spots of congenitally infected babies. J. Clin. Virol., 21(1), 75-79.

7. Boppana, S.B.; Rivera, L.B.; Fowler, K.B.; Mach, M.; Britt, W.J. (2001). Intrauterine transmission of cytomegalovirus to infants of women with preconceptional immunity. New Engl. J. Med., 344(18), 1366-1371.

8. Brown, J.M.; Kaneshima, H.; Mocarski, E.S. (1995). Dramatic differences in the replication of human cytomegalovirus in SCID-hu mice. J. Infect. Dis., 171(6), 1599-1603.

9. Chou, S.; Dennison, K.M. (1991). Analysis of interstrain variation in cytomegalovirus glycoprotein B sequences encoding neutralization-related epitopes. J. Infect. Dis., 163(6), 1229-1234.

10. Chou, S. (1992). Molecular epidemiology of envelope glycoprotein $\mathrm{H}$ of human cytomegalovirus. J. Infect. Dis., 166(3), 604-607.

11. Cranage, M.P.; Kouzarides, T.; Bankier, A.T.; Satchwell, S.; Weston, K.; Tomlinson, P.; Barrell, B.; Hart, H.; Bell, S.E.; Minson, A.C. et al. (1986). Identification of the human cytomegalovirus glycoprotein $\mathrm{B}$ gene and induction of neutralizing antibodies via its expression in recombinant vaccinia virus. EMBO J., 5(11), 3057-3063.

12. Drew, W.L.; Mintz, L.; Miner, R.C.; Sands, M.; Ketterer, B. (1981). Prevalence of cytomegalovirus infection in homosexual men. $J$. Infect. Dis., 143(2), 188-192.

13. Fidouh-Houhou, N.; Duval, X.; Bissuel, F.; Bourbonneux, V.; Flandre, P.; Ecobichon, J.L.; Jordan, M.C.; Vilde, J.L.; Brun-Vezinet, F.; Leport, C. (2001). Salivary cytomegalovirus (CMV) shedding, glycoprotein $\mathrm{B}$ genotype distribution, and CMV disease in human immunodeficiency virus-seropositive patients. Clin. Infect. Dis., 33(8), 1406-1411.
14. Fisher, S.; Genbacev, O.; Maidji, E.; Pereira, L. (2000). Human cytomegalovirus infection of placental cytotrophoblasts in vitro and in utero: implications for transmission and pathogenesis. $J$. Virol., 74(15), 6808-6820.

15. Fries, B.F.; Chou, S.; Boeckh, M.; Torok, B.S. (1994). Frequency distribution of cytomegalovirus envelope glycoprotein genotypes in bone marrow transplant recipients. J. Infect. Dis., 169(4), 769774 .

16. Ho, M. (1990). Epidemiology of cytomegalovirus infections. Rev. Infect. Dis., 12(Suppl 17), 701-710.

17. Humar, A.; Kumar, D.; Gilbert, C.; Boivin, G. (2003). Cytomegalovirus (CMV) glycoprotein B genotypes and response to antiviral therapy, in solid-organ-transplant recipients with CMV disease. J. Infect. Dis., 188(4), 581-584.

18. Keay, S.; Baldwin, B. (1991). Anti-idiotype antibodies that mimic gp86 of human CMV inhibit viral fusion but not attachment. $J$. Virol., 65(9), 5124-5128.

19. Klemola, E.; von Essen, R.; Henle, G.; Henle W. (1970). Infectiousmononucleosis-like disease with negative heterophil agglutination test. Clinical features in relation to Epstein-Barr virus and cytomegalovirus antibodies. J. Infect. Dis., 121(6), 608-614.

20. Lukácsi, A.; Taróbi, B.; Endreffy, E.; Bábinski, Á.; Pál, A.; Pusztai, R. (2001). Human cytomegalovirus gB genotype 1 is dominant in congenital infections in South Hungary. J. Med. Virol., 65(3), 537542 .

21. Lurain, N.S.; Kapell, K.S.; Huang, D.D.; Short, J.A.; Paintsil, J.; Winkfield, E.; Benedict, C.A.; Ware, C.F.; Bremer, J.W. (1999). Human cytomegalovirus UL144 open reading frame: sequence hypervariability in low-passage clinical isolates. J. Virol., 73(12), 10040-10050.

22. Meyer-König, U.; Vogelberg, C.; Bongarts, A.; Kampa, D.; Delbruck, R.; Wolff-Vorbeck, G.; Kirste, G.; Haberland, M.; Hufert, F.T.; von Laer. D. (1998). Glycoprotein B genotype correlates with cell tropism in vivo of human cytomegalovirus infection. J. Med. Virol., 55(1), 75-81.

23. Monforte, A.A.; Mainini, F.; Testa, L.; Vago, L.; Balotta, L.; Nebuloni, M.; Antinori, S.; Bini, T.; Moroni, M. (1997). Predictors of cytomegalovirus disease, natural history and autopsy findings in a cohort of patients with AIDS. AIDS, 11(4), 517-524.

24. Navarro, D.; Paz, P.; Tuzigov, S.; Topp, K.; Vall, J.L.; Pereira, L. (1993). Glycoprotein B of human cytomegalovirus promotes virion penetration into cells, transmission of infection from cell to cell, and fusion of infected cells. Virology, 197(1), 143-158.

25. Navarro, D.; Lennette, E.; Tuzigov, S.; Pereira, L. (1997). Humoral immune response to functional regions of human cytomegalovirus glycoprotein B. J. Med. Virol., 52(4), 451-459.

26. Nogueira, R.M.R.; Schatzmayr, H.G.; Assis, C.E.R.; Pinhão, A.T. (1986). Infecções pelo citomegalovirus e Herpes simplex tipo 2. Amostragem em crianças de baixa idade no município do Rio de Janeiro. Clín. Pediat., 10(1), 22-28.

27. Numazaki, K.; Ikehata, M.; Asanuma, H.; Chiba, S. (1998). Simultaneous infection of immunocompetent individuals with multiple cytomegalovirus strains. Lancet, 21(9141), 352.

28. Olson, L.C.; Ketusinha, R.; Mansuwan, P.; Snitbhan, R. (1970). Respiratory tract excretion of cytomegalovirus in Thai children. $J$. Pediatr., 77(3), 499-501.

29. Picone, O.; Costa, J.M.; Leruez-Ville, M.; Ernault, P.; Olivi, M.; Ville, Y. (2004). Cytomegalovirus (CMV) glycoprotein B genotype and CMV DNA load int the amniotic fluid of infected fetus. Prenat. Diagn., 24(12), 1001-1006.

30. Picone, O.; Costa, J.M.; Chaix, M.L.; Ville, Y.; Rouzioux, C.; LeruezVille, M. (2005). Human cytomegalovirus UL144 gene polymorphisms in congenital infections. J. Clin. Microbiol., 43(1), 25-29.

31. Pignatelli, S.; Dal Monte, P.; Landini, M.P. (2001). gpUL73 (gN) genomic variants of human cytomegalovirus isolates are clustered 
into four distinct genotypes. J. Gen. Virol., 82(Pt 11), 2777 2784.

32. Pignatelli, S.; Dal Monte, P.; Rossini, G.; Lazzarotto, T.; Gatto, M.R.; Landini, M.P. (2003). Intruterine cytomegalovirus infection and glycoprotein N (gN) genotypes. J. Clin Virol., 28(1), 38-43.

33. Rasmussen, L.; Hong, C.; Zipeto, D.; Morris, S.; Sherman, D.; Chou, S.; Miner, R.; Drew, W.L.; Wolitz, R.; Dowling, A.; Warford, A.; Merigan, T.C. (1997). Cytomegalovirus gB genotype distribution differs in human immunodeficiency virus-infected patients and immunocompromised allograft recipients. J. Infect. Dis., 175(1), 178-184.

34. Sinzger, C.; Plachter, B.; Stenglein, S.; Jahn, G. (1993). Immunohistochemical detection of viral antigens in smooth muscle, stromal and epithelial cells from acute human cytomegalovirus gastritis. J. Infect. Dis., 167(6), 1427-1432.

35. Spano, L.C.; Vargas, P.R.M.; Ribeiro, F.S.; Leite, J.P.; Nascimento, J.P. (2002). Cytomegalovirus in human abortion in Espírito Santo, Brazil. J. Clin. Virol., 25(Suppl 2), 173-178.

36. Spano, L.C.; Gatti, J.; Nascimento, J.P.; Leite, J.P. (2004). Prevalence of human cytomegalovirus infection in pregnant and non-pregnant women. J. Infection, 48(3), 213-220.

37. Stagno, S.; Reynolds, D.W.; Pass, R.F.; Alford, C.A.Jr. (1980). Breast milk and risk of cytomegalovirus infection. New Engl. J. Med., 302(19), 1073-1076.
38. Stagno, S.; Pass, F.R.; Dworsk, M.; Alford, C.A.Jr. (1982). Maternal cytomegalovirus infection and perinatal transmission. Clin. Obstet. Gynec., 25(3), 563-573.

39. Trincado, D.E.; Scott, G.M.; White, P.A.; Hunt, C.; Rasmussen, L.; Rawlinson, W.D. (2000). Human cytomegalovirus strains associated with congenital and perinatal infection. J. Med. Virol., 61(4), 481-487.

40. Trincado, D.E.; Munro, S.C.; Camaris, C.; Rawlinson, W.D. (2005). Highly sensitive detection and localization of maternally acquired human cytomegalovirus in placental tissue by in situ polymerase chain reaction. J. Infect. Dis., 192(4), 650-657.

41. Tuzigov, S.; Navarro, D.; Paz, P.; Wang, Y.; Qadri, I.; Pereira L. (1994). Function of human cytomegalovirus glycoprotein B: syncytium formation in cells constitutively expressing $\mathrm{gB}$ is blocked by neutralizing antibodies. Virology, 201(2), 263-276.

42. Vogelberg, C.; Meyer-König, U.; Hufert, F.T.; Kirste, G.; von Laer, D. (1996). Human cytomegalovirus glycoprotein B genotypes in renal transplant recipients. J. Med. Virol., 50(1), 31-34.

43. Yu, Z.S.; Zou, C.C.; Zheng, J.Y.; Zhao, Z.Y. (2006). Cytomegalvorius $\mathrm{gB}$ genotype and clinical features in Chinese infants with congenital infections. Intervirology, 49(5), 281-285.

44. Zipeto, D.; Morris, S.; Hong, C.; Dowling, A.; Wolitz, R.; Merigan, T.C.; Rasmussen, L. (1995). Human cytomegalovirus (CMV) DNA in plasma reflects quantity of CMV DNA present in leukocytes. $J$. Clin. Microb., 33(10), 2607-2611. 